\title{
FORMATION AND IMPLEMENTATION OF PUBLIC NEEDS AS A MEASURE OF IMPROVEMENT OF SOCIETY TERRITORIAL ORGANIZATION
}

\author{
Larysa BOGUSH ${ }^{1}$, \\ Institute of Demography and Social Studies of the National Academy of Sciences of Ukraine, Ukraine
}

\begin{abstract}
The purpose of the paper is to study the relationship of the formation and implementation of the range of social needs with the evolution and activity is focused on the improvement of the territorial organization of society. Methodology of research involves: the substantiation of the origin, factors for the development, approaches to classification, functions of public needs in the development of state and society; the study of the socio-humanitarian space of formation and realization of the needs of individuals, functional and territorial communities, as well as a mechanism of their satisfaction at the national and spatial scales (on the example of Ukraine - a country with a developing economy, wherein the decentralization of powers in the field social welfare and consolidation of local communities are implemented at present). Results. Summarized and proved the patterns and trends of development, evolution, transformation of needs of social groups, functional and territorial communities of the population, as well as the relationship of these processes with the economic and institutional capacities and mechanisms of satisfaction of the spectrum of social needs in consideration of peculiarities, achieved and desired parameters of development of productive forces, human and other components of the social and humanitarian potential, cultural features of the society. The development of the institutional, functional and territorial organization of society, in fact, is a process of formation and implementation in the range of human needs (individual and collective), which is estimated with the factors, conditions and mechanisms of their satisfaction, including through the dynamics of the positions of the spectrum of social groups and subjects concerning the required amount of vital goods consumption. Practical implications. Social and political transformation stimulates the establishment of the multidirectional formation in the Ukrainian economy of public goods, combining public and private (private commercial and non-profit) enterprises, institutions, organizations, that: provide services to the various strata of the population, which normalized within social guarantees volume and quality (based on public procurement, temporary contracts and corporate contacts, supported in the case of fulfillment of the conditions of resource intensity, the volume of budget financing, quality, terms of providing goods and services); are coordinated by budgetary and fiscal policy. Significant factors of development of local communities and improvement of the investment climate in the regions are: the provision of social mobility (basis - an adequate level of personal incomes, the implementation of state policy for employment creation and assistance in the household arrangement of hired employees); socio-economic activation of the population (through the promotion of entrepreneurship, self-employment and innovation activity of business entities, labor migrations, improvement of professional and qualification potential of labor resources). Value/originality. Regulation of the organizational and economic mechanism of implementation of legislative guarantees for consumption of socially necessary services, satisfaction of the individualized needs of the Ukrainian population, will contribute to: the improvement of the territorial organization of social infrastructure in accordance with the goals of the reform of administrative structure and enhancement the of the social powers of local budgets; increase of the effectiveness in processes of reproduction and the capitalization of socio-humanitarian potential.
\end{abstract}

Key words: public needs, social capital, welfare economics, public guarantees, socio-humanitarian space, territorial organization of society.

JEL Classification: D6, E61, H4, H54, 13, 015

\footnotetext{
Corresponding author:

${ }^{1}$ Department of Social Infrastructure, Institute of Demography and Social Studies of the National Academy of Sciences of Ukraine.

E-mail: bogush_lg@ukr.net
} 


\section{Introduction}

Social needs in their individual, collective, territorial and public measurements are permanent leading factor and indicator of socioeconomic development (including aspects of reproduction and capitalization of sociohumanistic potential, providing and improvement of organizational and economic mechanism, social services and protection of population). The reason of rapid development of social security system and social insurance, fast accumulation of investments for realization of above said functions and for the world leading countries from the second half of XX century (as well as expansion of welfare state idea with characteristics of relevant quality of life and social security of citizens) is seen in necessity of increasing legitimacy of development model realized by present-day leaders of global economy. In particular, it is about versatile assistance to the management structure based on the latest technologies, and the industry focused on the mass consumer (El'yanov, 2003).

Transformation human and other components of the social capital into the key factors of socio-economic progress of the countries at industrial and post-industrial stages of development confirmed the importance of social protection in state policy of ensuring stable growth rates, and components providing of national security (in particular, to provide public consent). It's based on the concepts of socially-oriented market economy and the social state, policy which is directed on the creation of allround conditions of person development and realization of its potential for worthy life providing with own hands. The social security is understood as legislatively recorded array of the social benefits which are undertaken with the state to make available to the citizens. The contents and basis of an institutionalizing are seen in social needs of the person as biosocial creature, exponents' satisfaction of which at all levels of society organization (individual, family, collective, all-civil) and resettlement (local, regional, and nation-wide), define quality of life.

Taking into account the motives for self-development, leading world states pay essential attention to regulation of labour-resources providing of local management systems, increasing of their functioning efficiency in a way of innovative realization potential of economically active population and widening of its productive employment sphere, supporting of social (including interethnic, interfaith) stability of territorial communities (Shlihter, 2002; Goffa, 2003; Lexin, Gritsyuk, Lexin, 2005).

In a way, the goal of the paper is the investigation of process interrelationship of formation and realization of a social needs range with evolution and purposeful activities for the territorial organization improvement of society. It presumes: justification of origin, development factors, approaches to classification, functions of social needs for development of the state and society; study of sociohumanistic space of formation and realization of individual needs, functional and territorial communities, and also the mechanism of their satisfaction at the nation-wide and spatial levels (in particular, on the example of Ukraine as emerging economies). Considering interdisciplinary categories, social needs, social capital, formation and realization of socio-humanistic space, the methodology of research which assumes generalization and coordination of the array of socio-anthropological, sociological, socioeconomical, economical and institutional, politological, culturological approaches which explain regularities and tendencies of formation, evolution, transformation of social groups requirements, functional and territorial communities of population, and also economic and organizational opportunities, mechanisms of their satisfaction taking into account features are reached of parameters in development of productive forces and sociocultural environment of society (Bogush, 2013).

\section{Origins and functions of social needs in state and social development}

The social needs of individual and population in present world are dual derivated of their biological and socially generated components and also above mentioned conditions and factors of formation and development of human populations and state society, supranational administrative formations. Thus, social requirements are based first of all on the original (primary) human needs with formation and changes of interpersonal, family, collective, public relations and interactions of individuals, social groups and layers evolve into the array of derivative (quasi) needs are defined with components of subjects behaviour which individually motivated and socially caused. Thus certain transformation, conditioned with standards of behaviour and features of interactions in society, other cultural influence and ideological factors continue to develop and suffer with the contents and mechanisms of satisfaction and natural need of individual. According to socially-economic approach, the main part of already mentioned needs (except for especially physiological), should be classified as the block of primary bio-social requirements connected with material and domestic providing, achievement and maintenance of life safety and environmental activity and also reproduction as social protection frame and translation of knowledge and experience within generations.

In the context of civilized development, social needs (first of all in organization of collective life, self-affirmation and implementation of leader functions, knowledge, amateur performance and self-realization) are considered as the highest goals of society activity which form its own values, in other words, abstract ideas which realize public ideals and thanks to it serve as a benchmark (Sydorchuck, Kozak, 2008). Social values are conviction about goals that should be achieved which wide known and recognized in society or social community and also ways and resources for their realization (Pavlychenko, Litvinenko, 2002). Therefore the basis of formation and regulatory function of valuable orientations of personal, establishment of which 
are an inherent aspect of all human socialization. Hierarchy of social and community values (the main categories include: theoretical, economic, political, law, moral, social, esthetical, and religious) defines the hierarchy of personal values and significantly influences on the history of society. Founding on its own values and valuable orientations, society, state, nation or certain social group create the standard of behaviour as requirements which are obligatory in a way of performance for life regulation and effective society functioning, adjustment of necessary members interaction (Shchokin, Popovich, Karmazina and others, 2000). The social norms are produced as public institute and authorities with the state are presented with constitutions, laws, the state industry, construction, sanitary standards and standards, instructions and other.

In the specified context (including aspect of set in life support systems) it is expedient to consider development of society, its functional and territorial organization as history of formation in a circle of personal needs, factors, conditions and mechanisms of their satisfaction and also with dynamics of social subjects' positions of the vital benefits volume, rather necessary for consumption. In a way, primary and derivative needs of individuals and social groups which form society, substantially comprise signs of mental structures and other properties of these subjects, significantly influence on architecture, the purposes and organizational and economic mechanisms of social and state functioning (thus, such institute based on the agreement of a certain territorial community concerning the acceptable forms of the relationship and interaction of all its groups and layers).

Considering requirements of own safety, a territorial community, the state and in general society process must regulate of formation and hierarchization of each their members' and social groups needs which appear in the course of education, work, communication and creativity in a certain cultural and social environment in process of acquisition in individual life experience and understanding of the socio-historical facts and regularities. The reference point provides rationing and control of corresponding process needs satisfaction for the established socially necessary volume and on the political and development stability.

Social component (characteristics of human resources; estimates of a demographic situation and criminogenic risks; indexes of labour and educational capacities of the region, its consumer market and communication infrastructure) was approved in estimate techniques of investment appealing of the countries and regions long ago, supplementing the indicators resulting from a level of development and efficiency of the human capital using (an assessment of economic development and potential, the characteristic of a level of development of the market relations and business, including a role in these processes of local authorities, tax system, financial sector and potential, market infrastructure) (Umanets, 2006). The leading selection criteria of the "problem" regions first of all needing the help to the central power in the sphere of creation of incentives of self-development (along with degree of development of production) are admitted the unemployment rate and prospects of expansion of employment (Schlichter, 2002; Goffe, 2003; Leksin, Gritsyuk, Leksin, 2005).

\section{Classification, evolutional factors of social needs}

Origin and evolution of human needs and society (as the highest level of self organization of populations' living at the certain territory based on the general population origin and also community of emotional, language, communicational, professional, legal, and spiritual types of interaction (Boronoev, Smirnov, 2003) which found similarities in a list of such models and their classification. These models (A. Maslow, Zh. Godfrua, B.V. Prykin, F. Hertsberg, D. McKleland, K. Alderpher and others) are fully coordinated and interrelated don't looking at the difference in in basic types of creation and level of generalization and considering the principal of primary needs transformation (Tarnavskaya, Pushkar', 1997; Meskon, Albert, Hedowry. 2000; Khramov, Bovtruck, 2001; Kolot, 2002; Hordey, 2003; Oganyan, Palamarchuk, Rumyantsev and others, 2003).

Beside with actualization of the highest level needs in the process of full satisfaction in the lowest their types, mentioned above classification models of social needs, help to make such conclusions:

- full satisfaction of the lowest level needs, connected with different aspects of life organization and providing of life security isn't the exceptive condition for formation and needs satisfaction of higher level (intellectual, self realization and moral development).

- system of human needs in society forms and realizes with inseparable entire and algorithm in post-industrial societies and as a rule it doesn't correspond with on individual and collective (communal) levels of stable hierarchy and allow possibility about existence of some dominate needs;

- actualization of certain needs in the process of their variety satisfaction can be realized according not only to the certain socially accepted group or hierarchical algorithm family but also to the dependence of dynamic, technical life conditions, material possibilities and morally-ethnical postulates of person relatively to gradation and needs satisfaction.

- the influence on value marks, life and development of personal needs of lower level makes stronger with existence in society objective and subjective difficulties for needs satisfaction of the higher level.

- to the objective needs are included first of all difficulties generated of social system with the attributes of property separations' deepening and formation of divisional society which is characterized with low-paid job for most wage and self employed workers and also a list of limitations in ensuring of vertical social mobility of population and 
territory mobility of legally employed. As the result the prorated layers of workers and as a particular can't fully satisfy needs in competitive able education, creasing of qualification and retraining, carrier development;

- technical and technological features of countries development, in the periods of social and economical irregularity, crisis of researches and natural cataclysms and others.

Subjective difficulties are connected with psychological features and individuals and social groups which are derived from moral and ethical doctrines don't looking at level of material prosperity which are dangerous with consumer-oriented mind attitude, nepotism, decrease in requirements, lumpenization and asocial marginalization and as the result - degradation of development potential of society in the format of existing civil and political order.

Considered above regularity of origin and evolution of personal and social needs and also ways to their classification may be generalized with the help of hierarchical model which includes the next kinds of needs classified in order of intensification of their evolution and historical development of human and society:

- physiological, material and common needs (food, drinking, housing, habitat of acceptable quality, satisfaction of other physiological and domestic needs including concerning of a reproduction and the organization of a desirable lifestyle)

- needs of security (in feeling of the individual security and communities to which it belongs, in predictability of personally significant spheres and directions of activity, in health);

- needs of acquiring and straightening of social status (in a personal inclusiveness in society and certain community, in adequate perception around people, including in the family relations, career, leadership, etc.);

- needs of adoption (achievement of success and competence, approval and respect);

- informative needs (in knowledge and abilities, in research, understanding and under-standing, in accumulation and the analysis of experience);

- moral and religious and esthetical needs (in harmonization of the personality, society and environment, in particular in aspects of the organization of conditions and a way of life);

- needs for self-realization and self-updating (in the fullest realization and understanding of incentives of selfdevelopment of internal creative, professional and spiritual potential of the personality, in understanding of social responsibility)

Considering the hierarchy and content of social needs array of human, social groups and whole society in general which socially-economic context must be outlined:

- on a functional purpose in the context of arrangement of activity and realization of system of values - material and household and welfare;

- according to historically developed mechanisms of requirements satisfaction - public (in their structure - general and socially necessary, formed and realized at the nation-wide, collective and individual levels), and also private;

- on emergency for the individual and social groups daily, periodic and incidental (it, in turn, created classification of consumer goods and services with the specified demand frequency, the territorial organization of the related economic activity and infrastructure).

The main factors of development and actualization of social needs are:

- scientific-technological (first of all state level features of scientific-technological progress, dynamic of modern circles and technically-technological statute);

- target and productive parameters of social development macrosystem (features and effective parameters of differentiation, including division with to property signs, level and ratio of the monetary and cumulative income, volumes of consumption of socially necessary material and household and welfare goods and services; education level, social and labour mobility of the population in a regional section; the contents and evolution of approaches to determination of volumes and structure of a state order for training of workers and experts, level of compensation, privileges and social benefits, to the taxation of labour and investment incomes, rendering primary and specialized medical care, provision of housing is low and the middlepaid of layers, the organizations of access to information sources, spiritual and historical and cultural property);

- culturally-ideological parameters (way of life of social groups and layers; the inherited and apprehended family, public and religious installations of worthy socioeconomic and household activity; the content of ideologies of national and ethnic self-identification of the population in aspects of the tolerant attitude towards representatives of other people, cultures and religions, opportunities and means of assimilation in society, including the acceptable types and mechanisms of economic activity and cooperation).

In globalization conditions of socially-economic processes of states functioning and national management system (as developing and which got the post-industrial level of developing) to main evolutional tenders of needs should be applied in the aspects:

in aspects civilization and society-creativities:

- recognition of people equal rights on physical, intellectual, spiritual development and socially useful self-realization, and also a number of basic freedoms of the personality that provides creation of opportunities for achievement of a pyramid of requirements by each individual of top under an indispensable condition of fuller satisfaction of their basic types in material and household arrangement and ensuring safety of the environment of activity;

- globalization of developments, substantial filling and an hierarchization of needs for borders of the countries, their political and economic associations, and also on a global scale along with an individualization of requirements (first of all the highest); 
in aspects of political, organizational and economic:

- the constitutional recognition of the state concerning obligations their satisfaction in so-called socially necessary volume, formation of the contents and rationing of the corresponding guarantees that provides in particular standard and legal and target financial security (including standardization and control) activity in the sphere of production of goods and services, and also the development and improvement of the territorial organization of infrastructure intended for implementation of these obligations;

- realization of ideologies of filling of requirements of the highest levels (informative, in achievement of professional competence and the social status, satisfaction with parameters of personal realization) the contents consolidating society, derivatives of that are maintenance of political stability and national security, formation of actual social security systems, creation of potential of self-development of territorial communities, socially responsible orientation of business;

in aspect production and technological:

- orientation to industrial technologies of satisfaction of requirements along with transition from mass to the individualized consumption of the corresponding goods and services are organized thanks to marketing of their markets (as to the integral element of addressing of the state social security and profitability of business activity), to development of interactive forms of satisfaction of requirements (including trade catalogue, electronic and exit, remote services of education and medical consultation);

- socially-conscious optimization and reduction of material and household needs for interests of decreasing resource-and power consumption of economy, mitigation of negative anthropogenic effect on environment.

\section{Socio-humanitarian space of social needs realization}

The space of social and human (collective and interpersonal) relationship and connections or sociohumanitarian which is localized in administrativelyterritorial separating with array of immanent and biosocial human nature and popularity of relationship within main social institutes families, territorial and functional civil communities, state economy, the (i.e. between individuals, their groups and associations on status signs and the place of residence, subjects of managing and their associations, institutes of rationing, management and control of all activities' spheres) concerning distribution and consumption of the benefits are created in a social production (material and non-material), reproduction, improvement and involvement of productive forces of the individual in economic activity (first of all her motivations and remuneration, external and in particular social efficiency). The purpose of these relations is formation and maintenance is wished (i.e. recognized expedient and rational, considering the available natural, material, human resources and reproduction conditions) social hierarchy, level and quality of life, the spatial organization of the environment of activity of society, and also level of coherence of interests of nationalities and faiths in regional, general and supranational scales (Bogush, 2010).

The material basis of establishing and functioning of socio-humanitarian space are such public institutes, objects, their multipurpose networks and systems which for achievement, an institutionalizing and expansion of powers of authority, satisfaction of material and nonmaterial requirements, an exchange of products of managing and interaction (with maintenance of certain levels of communication, trust and consent), accumulation, an exchange, transfer and converting of knowledge, cultural experience and heritage, promoting of beliefs and creativity are created by individuals, collectives, territorial communities, other communities (voluntary associations) of compact accommodation, conducting, economic and culturally-religious activity.

In historical development socio-humanitarian space of compact living and housing in concrete human population, the list of steps happens from the array of hierarchicallyhumanitarian relationship in family and culturallyreligious community to the system of social relationship about involvement into the production, reproduction, improvement and ensuring of full realization of production possibilities of human. The certain organization of distribution and consumption, forms the basis of above said processes which can satisfy the human needs and also the practice of realizing and participation to this ethnicallyculturally-religious and socially-political heritage and traditions. It considers the deepening of connections between social institutes, ensuring of mechanism stability and tendencies for their interactive, complex of correspond infrastructure about functional and territorial indicators or with other words the creation of balanced system of social, communal and interpersonal relationship and connecting which defines and leads all spheres of human life.

The synergetic effect of formation and developing of socio-humanitarian space (which made stronger or fainter the existent connection and regularities of its functioning is brightly showed in demographical and ethno-national processes. The features of all-national identity of population in certain country in general and concrete citizen are provided with its' historical experience, subjective realizing, dynamic of material position, self-realizing of social status and other circumstances which may be generalized with level of life satisfaction (Horshkov, Tikhonova, 2008). Demographical and ethnographical components of stability and balance of socio-humanitarian space it's useful to under-stand as protection of living process and endless, natural and social reproduction of generations as representatives of title nation and racial minorities which are populated in certain region (country); their improvement is connected with increasing of life duration; increasing of demographic reproduction efficiency, getting a balance between array of national interests and 
needs, ensuring of ethnographic and gender tolerance and equivalence (Nikitenko, Solodovnikov, Chernysh, 2008).

Pointed main features of socio-humanitarian space tell about opportunity of complex research about content, connections and interactions of its subjects, mechanisms and forms of organization in territorial and time aspects which in particular, appear in such important characteristics of certain territory (local system of resettlement, region, district, etc.) as:

- level of its saturation with array of material elements which form and ensure of functioning of sociohumanitarian space (objects and networks of organization non-production life with resource potential such as main founds, financing and staff). This level is showed in indicators of their territorial resettlement (namely differentiations, concentration, uniformity of placement in the territory of the population and economic activity on satisfaction of his material and household and welfare requirements), which first of all depend on the organizational form of management and resettlement.

- level of connectedness, in institutional and functional structures of socio-humanitarian space in local system of resettlement in region or country in territorial and time aspect (complexity and quality of nomination and regulation of activity about realization and improvement of human production possibilities, distribution and consumption of material and non-material goods which were created in social production and satisfy an array of its' needs; level and conditions of horizontal and vertical social mobility);

- socially-economical results of activity for satisfaction in materially-economic and socio-cultural needs; which are used for estimating of state efficiency.

Institutional characteristics of socio-humanitarian space are provided with qualities and dynamic of main social institutes:

- economical (in particular property and coordination of management activity)

- legal, including dominate institute of recourses circulation such as material, financial, political and others thanks of which infrastructure satisfies the non-production social needs (in the same time the legal institutes service as indicators of stratification and status structure of society);

- cultural (in the realizing of ways to institutionalization of moral, ethic, ideology as the basis of formulation and development of cultural subsystem of socio-humanitarian space).

\section{Mechanism of social needs satisfaction at the national and territorial level}

Actual problems in social ensuring of territorial community in the conditions of transitional economy is the disbalance of correspond legislative guaranties, level of their budgets and non-state financing, incompleteness and contradictions in normative base of resources supply for activity of satisfaction in necessary materially-economic and socially-cultural personal needs and regional communities, low efficiency of realization mechanism.
The notions of social (socially needed) and private goods and services are the principal basis of mechanisms of legal power spreading in state affairs with the satisfaction of different individual, communal, social levels.

The commercial goods are created with individual and corporative producers for satisfaction of personal needs or their voluntary communities and realizing on the free market in correspondence with connection of supply and of solvent demand. In a way, the production volumes of social goods which are used for common (paid and free) consumptions and are set with the affairs of state power in dependence on estimation of correspond social needs which is fixed in legislative guaranties as the result of historical consensus of social groups and layers (the coordination of state and social positions at the modern staged in democratic countries) with the reason of conditions about social association (state) and ensuring of stable existence. Market regularities of supply and price creation of social goods must to be connected only with correspondence of production spending and volume of given social (include budget) resources (Knyazev, 2008).

The ensuring of legal order, road building, arrays of ingénue networks and infrastructure (which is needed for normal living of society) are especially-social goods (in mean of undivided by using) (Elyanov, 2003). The list of socially needed goods may be defined with the actual social guaranties and legislatively formed standards of their realization (to rational and minimal norms) and also with the directions of state interference in market economy with the purpose of providing of stable management activity, compensation of problem and negatives of free market. In such way they include:

- development of education (first of all the rapid development and providing of common and wide access to high and secondary education), medical care (include the balancing of informational streams between producers on the market of medical services and their consumers), science and culture which are important for wealth existence of population, improvement of social capital components.

Providing of basic (fundamental) of scientific researches, improvement of transport and communicational infrastructure with the goal of getting the multiplication effect with the means of technological innovations and improvement of production quality in different fields;

- antimonopoly regulation in production and distribution of energetic, transport and other communicational services;

- system of social transfers, donations and subsidies;

- special protection within non-inflation regulation (Elianov, 2003).

Market theory of production location (in particular, the theory of central places and transactional analysis) which is the principal for methodology of stable social development of regions and territory communities admits goods and services distribution by the bargained and nonbargained. 
Goods of long-term using, self fabricated materials, services in the field of R\&D (Research and Development), medical care, education, banc activity, tourism and among goods and services of the second category - the land and real estate objects, services in realization of goods, primary and secondary education, part of utilities, except for gas supply and the electric power, and also communication services, a number of credit and medical services) that are first goods which may be transported from sender to recipient (Orekhovsky, 2008).

With the opportunity of transportation, this separation is based on the differences in the methods of price creation if in the correlation of bargain goods and services form prices which are negligibly vary within the country (but close to worldwide prices in the conditions of open economy), so prices on non-bargain goods and services are isolated within local markets and that's why the interregional prices between differs in several times (by the world comparing in several dozen times). Thus, benefits are generated with the supply of bargain production which is made with the main management subjects - the participants of the territorial separating of labour define the level of wealth of local population, level of prices depends first all on its' solvent supply.

Low market efficiency in the sphere of its' production of social goods is admitted as a key factor in formation of budget sector. As the result, economic subsystem for personal and common needs satisfaction. The permanent problem of market and budget trade off is important for functioning of this system (Zyatkovsky, 2006).

The fractional aspect of this decision about production of social goods is the state and private partnership which is management form based on the institutionallyorganizational union of state and private business which is established with the goal of realization of socially important projects (from municipal to national and international). It was based on the contract or concessional depute for undetermined period to physical person some part of economical, organizational and control functions in relative to public-legal property namely the state and municipal objects and services, natural resources, monopoly of the state for a number of kinds of activity (thus the mentioned objects don't change form of ownership) (Varnavskiy, 2002).

Institutionally-legal base of PSPP (Partnership of State and Private Property) first of all created with statutory instruments which connected with differentiation of state, regional and local power (particularly with current decentralization of power in Ukraine, which is accompanied with translation of wide spectra of social functions into the managing of united territorial communities and local budgets). It should promote the autonomy of municipal affairs as legal person within empowerments are considered with contracts and concessions.

National authorities depute objects of social sphere, gas and power economy, water supply and the sewerage, transport and communication systems, government buildings and constructions, sign agreements on rendering of services on the maintenance of social infrastructure, in spheres of health care, education and professional development of labor, support of socially vulnerable groups of the population, overcoming of excessive social differentiation, R\&D (Research and Development), environment protection, city planning to private property or terminal owning and regulating of private capital. Correspond contracts of regional and local levels are usually connected with developments and modernizations of settlements, their social security and the sphere of leisure, providing design, reconstruction, construction, equipment, management and the content of social objects, supply of their visitors with food, information equipment, etc (Sorokina, 1999; Varnavskiy, 2002). As the result, the increasing of mobility to the social requirements, assignment of more quality goods and services by the lower smaller expenses of production, decrease in load of budgets of various levels, refusal of the state and municipal sectors of inefficient forms of managing are combined with organizational experience, innovational and financial potential of private property.

In a way, in production of social goods to regional and territorial communities of Ukraine during decentralization of empowerments and realization of administrate form are defined: the state and municipal subjects are financed from budgets of various levels; the state and municipal subjects who, together with the budgetary resources, operate with receipts from providing paid services to natural and legal entities; the non-state actors functioning on the enterprise or non-profitable beginnings, whose activity is provided with the state order and contracts (including PSPP), receipt of funds from providing paid services to various categories of consumers, non-state funds, patrons, sponsors.

\section{Conclusions}

Development of institutional, functional and territorial organization of society, mainly is a formational and realization process of needs circle of person (individual and collective), which are estimated with factors, conditions and mechanisms of their satisfaction, including dynamic in variety of social communities and subjects in relation to necessary volume of life goods consumption.

Researching results admitted the necessity of social goods formation in the economy of Ukrainian multidirectional education which combines state and non-state (private, commercial and non-commercial) enterprises, establishments, organizations, which services to different layers of population within certain volume quality of social security (based on the state order, temporary contracts and corporate non-market affairs supported in case of performance of conditions by the parties concerning resource intensity, volumes of the budgetary financing, quality, terms of granting goods and services) and in summary it's coordinated with state social and fiscally-budget policy. Supplementing each other, the state and noncommercial sectors of social sphere in 
the country and regional social complexes are capable to capture all space of legislative obligations of cultural and community service of the population.

Mechanisms which contents and productivity of actions for the solution of interaction state problems and private (including noncommercial) sectors in regions and resettlements of Ukraine, as well as public consequences of transfer to the private sector of the social security functions which are traditionally stay in the state competence will depend on a level of control structures development activity of authorities (including within civil society), bases (among other things - transparency) business and partner activity.

Socially-oriented market economy predicts the leading with the state of corrective activity in sphere of macroeconomic regulating in social sphere with the directions, which ensure market development as sociallysimulative process(by creation of conditions for equal competence prevention of monopolies, restriction of overproduction, dumping prices and other factors of crisis). Together with optimization of branch, territorial and investment streams other important factors for improvement of investment climate in regions are:

- providing of social mobility (based on the socially level of civil profits, realization of measurement in state policy about self regulation of territory disproportions by the creation of new job places and assistance to arrangement of necessary staff);

- popularity "activation" (during the stimulated entrepreneurship, self employment and innovational activity among the subjects of managing, push-pull and interregional labor migrations, improvement of qualification potential of labour resources according to needs of the concrete region).

Regulation of economically-organizational mechanism about realization of legislative liabilities which are connected with consumption of socially-needed services and also for satisfaction of personal needs of Ukrainian popularity, demands the following researches of problem and methodology as improvement of territorial organization of social infrastructures of in regional local system of resettlement, so in the providing of stability in the processes of its' financing in the condition of powerful influence of subjective factors are connected with subjection of the lowest networks of objects and disadvantages of hierarchy functioning in the questions of regulation and correction of quality indicators of their development and professional activity.

\section{References}

Bogush, L. G. (2010). Sotsialniy kaptal i sotsiogumanitarniy prostir: metodologiya viznachennya, vzaemozvyazki, vektori rozvitku. EkonomIka ta derzhava, 4: p. 15-20.

Bogush, L. G. (2013). Sotsiaini prioriteti stalogo rozvitku Ukrayini: kriteriyi formuvannya, politika realizatsiyi. Ekonomika ta derzhava, 12: p. 34-39.

Boronoev, A. O., Smirnov, P. I. (2003). O ponyatiyah «obschestvo $\mathrm{i}_{\text {}} \ll$ sotsialnoe». Sotsiologicheskie issledovaniya (SOTsIS), 8: p. 3-11.

Varnavskiy, V. (2002). Partnerstvo gosudarstva i chastnogo sektora: teoriya i praktika. Mirovaya ekonomika i mezhdunarodnyie otnosheniya, 7: p. 28-37.

Gordey, O. D. (2003). Modeli derzhavnogo regulyuvannya dobrobutu naselennya. Finansi Ukrayini, 11: p. 51-57. Gorshkov, M., Tihonova, N. (2008). Samoidentifikatsiya grazhdanina Rossii: sotsiologicheskiy zamer. Obschestvo i ekonomika, 1: p. 42-72.

Goffe, N. (2003). Sotsialnaya sostavlyayuschaya regionalnoy politiki na Zapade. Mirovaya ekonomika i mezhdunarodnyie otnosheniya, 4: p. 63-70.

Zyatkovskiy, I. V. (2006). Finansove zabezpechennya byudzhetnih ustanov v umovah reorganizatsiyi sferi vyrobnitstva suspilnih blag. Finansi Ukrayini, 1: p. 13-23.

Knyazev, Yu. (2008). Evolyutsiya ekonomicheskoy teorii: ot ryinochnogo liberalizma k sotsialnomu regulirovaniyu. Obschestvo i ekonomika, 3-4: p. 19-44.

Kolot, A. M. (2002). MotivatsIya personalu. - Kiyiv: KNEU.

Leksin, I. V., Gritsyuk, T. V., Leksin, A. V. (2005). Region kak ob'ekt analiza i gosudarstvennogo upravleniya. Regionalnaya ekonomika: teoriya i praktika, 4: p. 20-26.

Meskon, M. H., Albert, M., Hedouri, F. (2000). Osnovyi menedzhmenta. - Moskva: Delo.

Nikitenko, P., Solodovnikov, S., Chernyish, S. (2008). Demograficheskaya bezopasnost i vneshnyaya migratsiya naseleniya. Obschestvo i ekonomika, 6: p. 3-11.

Oganyan, G. A., Palamarchuk, V. O., Rumyantsev, A. P., ta In. (2003). Politichna ekonomiya. - Kiyiv: MAUP. [Electronic resource]. - Retrieved from: http://fingal.com.ua/content/view/482/39/1/4/

Orehovskiy, P. (2008). Faktor prostranstva v transaktsionnom analize. Obschestvo i ekonomika, 6: p. $12-27$.

Pavlichenko, P. P., Litvinenko, D. A. (2002). Sotsiologiya. - Kiyiv: Libra.

Sidorchuk, O., Kozak, I. (2008). Osoblivosti formuvannya ta perspektivi vIdrodzhennya sotsialnogo kapitalu. Efektivnist derzhavnogo upravlinnya, 16/17: p. 377-388.

Sorokina, V. (1999). Velikobritaniya: chastnaya finansovaya initsiativa. Mirovaya ekonomika i mezhdunarodnyie otnosheniya, 1: p. 90-95. 
Tarnavska, N. P., Pushkar, R. M. (1997). Menedzhment: teoriya ta praktika. - Ternopil: Kartblansh.

Umanets, T. V. (2006). Otsinka investitsiynoyi privablivosti regionu za dopomogoyu integralnih indeksiv. Ekonomika i prognozuvannya, 4: p. 133-145.

Hramov, V. O., Bovtruk, A. P. (2001). Osnovi upravlinnya personalom. - Kiyiv: MAUP.

Shlihter, A. (2002). Mestnoe samoupravlenie v sisteme federalizma: problemyi Rossii i opyt Ameryki. Mirovaya ekonomika i mezhdunarodnyie otnosheniya, 6: p. 45-54.

Schokin, G. V., Popovich, M. S., Karmazina, M. S., ta in. (2000). Ukrayina na zlami tysyacholit: istorichniy ekskurs, problemi, tendentsiyi ta perspektivi. - Kiyiv: MAUP.

Elyanov, A. (2003). Gosudarstvo i razvitie. Mirovaya ekonomika i mezhdunarodnyie otnosheniya, 1: p. 3-14.

\section{Лариса БОГУШ}

\section{ФОРМИРОВАНИЕ И РЕАЛИЗАЦИЯ СОЦИАЛЬНЫХ ПОТРЕБНОСТЕЙ КАК КРИТЕРИЙ СОВЕРШЕНСТВОВАНИЯ ТЕРРИТОРИАЛЬНОЙ ОРГАНИЗАЦИИ ОБЩЕСТВА}

Аннотация. Целью работы является исследование взаимосвязей процессов формирования и реализации спектра социальных потребностей с эволюцией и целенаправленной деятельностью по совершенствованию территориальной организации общества. Методика исследования предполагает: обоснование происхождения, факторов развития, подходов к классификации, функций социальных потребностей в развитии государства и социума; изучение социогуманитарного пространства формирования и реализации потребностей индивидов, функциональных и территориальных сообществ, а также механизма их удовлетворения на общегосударственном и пространственном уровнях (на примере Украины - страны с развивающейся экономикой, где ныне осуществляется децентрализация властных полномочий в сфере социального обеспечения и укрупнение низовых территориальных общин). Результаты. Обобщены и обоснованы закономерности и тенденции становления, эволюции, трансформации потребностей социальных групп, функциональных и территориальных сообществ населения, а также взаимосвязь этих процессов с экономическими и организационными возможностями и механизмами удовлетворения спектра социальных потребностей с учетом особенностей, достигнутых и желаемых параметров развития производительных сил, человеческого и прочих компонентов социогуманитарного потенциала, социокультурной среды общества. Развитие институциональной, функциональной и территориальной организации общества, по сути, является процессом формирования и реализации круга потребностей человека (индивидуального и коллективного), который оценивается через факторы, условия и механизмы их удовлетворения, в том числе через динамику позиций спектра социальных групп и субъектов относительно необходимого для потребления объема жизненных благ. Практическое значение. Общественно-политические трансформации стимулируют формирование в экономике общественных благ Украины многосекторного образования, сочетающего государственные и негосударственные (частные коммерческие и некоммерческие) предприятия, учреждения, организации, которые: оказывают различным слоям населения услуги нормированного в рамках социальных гарантий объема и качества (на основе госзаказа, временных контрактов и корпоративных внерыночных связей, поддерживаемых в случае выполнения условий ресурсоемкости, объемов бюджетного финансирования, качества, сроков предоставления товаров и услуг); координируются государственной социальной и бюджетно-фискальной политикой. Весомыми факторами развития территориальных общин и улучшения инвестиционного климата в регионах являются: обеспечение социальной мобильности (основа - достаточный уровень доходов граждан, реализация государственной политики по созданию новых рабочих мест и содействию бытовому обустройству кадров); «активизация» населения (через стимулирование предпринимательства, самозанятости и инновационной активности субъектов хозяйствования, трудовых миграций, совершенствование профессионально-квалификационного потенциала трудовых ресурсов). Значение/оригинальность. Урегулирование организационно-экономического механизма реализации законодательных гарантий потребления общественно необходимых услуг, удовлетворения соответствующих индивидуализированных потребностей населения Украины будет способствовать: совершенствованию территориальной организации социальной инфраструктуры в соответствии с целями реформы административного устройства и усиления социальных полномочий местных бюджетов; повышению эффективности процессов воспроизводства и капитализации социогуманитарного потенциала. 